\title{
Tendencies of Small Business Development in the Russian Information Economy
}

\author{
Garifova L.F. \\ Kazan Federal University, Institute of Management, Economics and Finance, Kazan, 420008, Russia \\ Email: Igarifova@mail.ru
}

Doi:10.5901/mjss.2014.v5n24p336

\begin{abstract}
The problem of small businesses products and services promotion with the using of new information technologies is considered in the article. The particular attention is paid to small businesses products and services promotion through social networks, especially on the Russian level. There is observation of the small businesses economic activities and social networks, which are preferable for a small business development. The basic ways of products and services promotion on social networks have been found out and there are given some recommendations on the most successful and rapid onset of the consumer audience attracting campaign. The proposed method of indicator calculation which shows the number of potential buyers will allow to calculate the approximate number of potential buyers for any business account in Instagram.
\end{abstract}

Keywords: small business, enterprise, the information economy, the information technology, social network, Instagram.

\section{Introduction}

The growing interest to the problem of small businesses products and services promotion using the new information technologies in the recent years is related to the society awareness of the information economy global development, the modernization of the economic potential through the development and implementation of the information technology.

In the available domestic and foreign literature the study of small businesses products and services promotion problems through the social networks, especially on the Russian level has an episodic nature. In these circumstances, it is necessary to light the issue since exactly Russian small business, today, is more than just interested in the following: sales increasing, attracting new customers, promoting their products and services in the information economy through the new information technologies application.

In connection with the foregoing there have been made an attempt to observe some small businesses economic activities and social networks, which are preferable for a small business development; to identify the main ways of products and services promoting in these networks, to give some recommendations on the most successful and rapid onset of the consumer audience attracting campaign

\section{Literature Review}

In this article we are going to consider enterprises of small businesses. According to statistics the number of small businesses is increasing annually: in 2001 there were 1 million 836 thousand enterprises of small businesses the number of small businesses enterprises in Russia in 2013 has exceeded 2 million. Such indicators as population growth and the number of Internet users in Russia also increased. (Figure 1). 


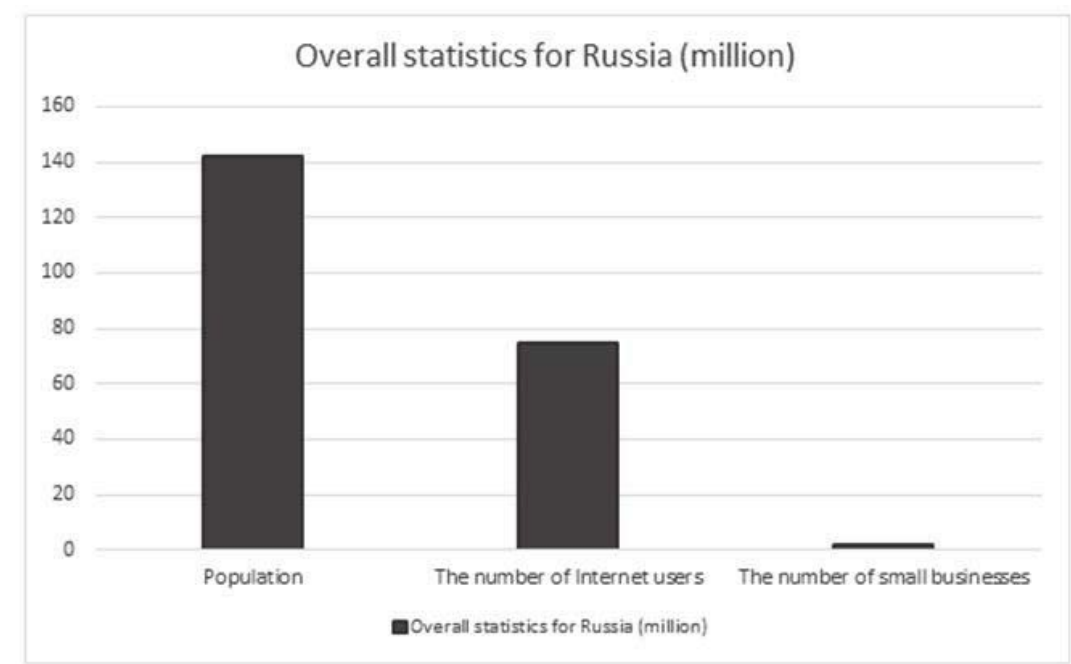

Figure 1: Overall statistics for Russia [1].

The proper promotion of business in the information economy -the promotion of business in cyberspace may be the key of a great success. It is important to note that Internet trading became a serious competitor to the common shops, and the Internet has won the trust of customers. Under conditions of economic uncertainty, consumers are spending more and more time looking for profitable offers. The time spending to the decision making process of purchases increases. Nowadays the Internet has become the very universal tool for market research. The consumers could hardly make a purchase without first examining the product and manufacturer reviews in the internet. More and more people before decision making need to read reviews and ratings of other users about products and stores. For this purpose one can increasingly use the search engines, services of comparative technical and price analysis and social networks. Products as varied as software, credit cards, and even coffee makers are influenced by network effects whereby the product's value is contingent upon the number of people using it [2]. With the help of blogs, newsletters, social networks, video and other marketing businesses can build relationships and get credibility and trust with its audience and ultimately increase sales [3].

When deciding which platforms to invest in, it's important to determine where your target market is active, and also which ones your competitors are using successfully [4].

Promoting small businesses enterprises in the social networks makes it possible to influence on the target audience, select the site place where the brand audience is represented to a greater extent, and the most appropriate ways to contact with it not affecting those who are not interested in the advertisement. The predictions of growing consumer power in the digital age that predated the turn of the century were fueled by the rise of the Internet and then reignited by social media [5].

It is necessary to mention the Social media marketing - it is a set of actions on the use of social media as channels for business promoting and attention and traffic attracting to the brand or to the product as well as the various tasks which are set by the company. Social media is an ideal environment for building brand communities [6].

Today there are more and more social networks in Russia and they are open to all Internet users. Their information is accurate, they also provide great opportunities for the target audience searching. The goal of any social network is a community of people that bring something in common (school, relax, work, interests). In the context of advertising technology it is very profitable - it is possible to attract a certain group of people for a particular advertisement. Leveraging the power of content and social media marketing can help elevate ones audience and customer base [7].

\section{Research}

Active development of social networks and services in recent years has had a strong influence on the information economy development, on the way how millions of consumers make purchases, take sellers. Such services as social networks, blogs and microblogs manage to attract an audience of millions. Also the world's largest companies, including market leaders in the retail trading and food production use the Internet in their strategy, as their target audience, their customers are exactly in the Internet.

As an object of the study the author in this paper selected 3 main Russian social networks: 1 - Vkontakte, 2 - 
Odnoklassniki, 3- Instagram. Processed statistics showed that in fact a huge part of the population visits social networks and a leader among them is a Vkontakte site - $62 \mathrm{mln}$ monthly visits. (Figure 2).

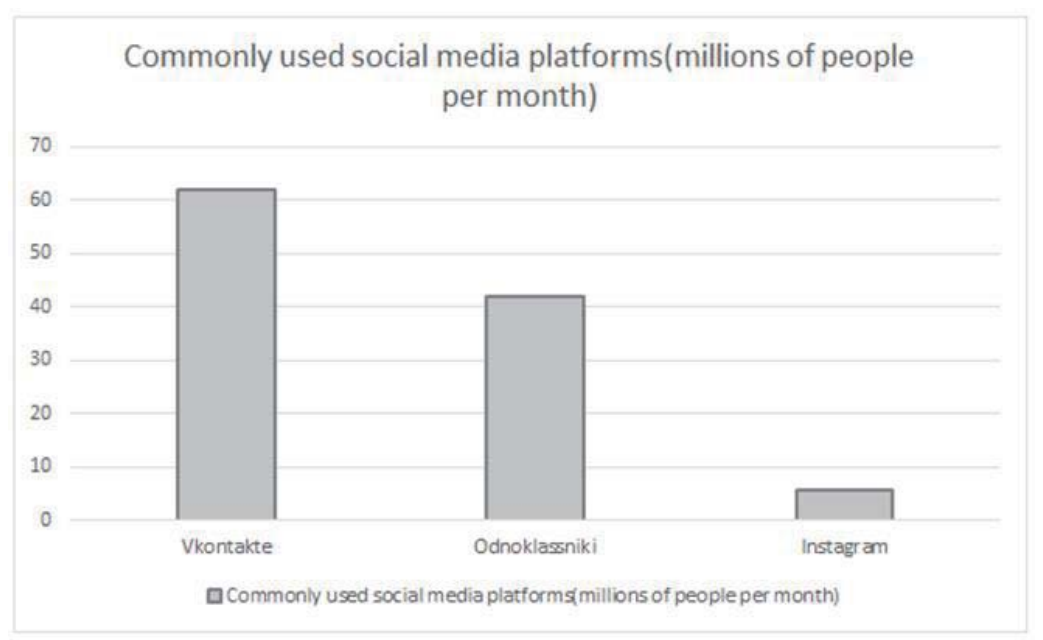

Figure 2: Commonly used social media platforms (millions of people per month)[1;8]

Nonlinear dynamic model has been suggested for assessing and predicting the number of social network users.[9] However, the growing popularity of network Instagram with more than $5 \mathrm{mln}$ people visits per day, will soon catch up with its main competitors. Instagram is the hottest social media site today: Two years after its launch, the number of its daily mobile users surpassed that of Twitter. Then Facebook purchased it for a billion dollars-and it took the world by storm [10].

People began to devote more time to examine proposals of the mass market, which is another qualitative shift in the consumer behavior. Statistics shows that the number of queries in search engines for high-value goods, such as cars and large household appliances are comparable to the number of user queries for animal feed and hair care.

Taking into account the impact of the economic downturn in the nearest future, consumers will spend more time looking for discounts and special promotions and examining sites with price comparisons and user reviews. Internet space becomes one social community and consumers listen to the opinion of other members even if they are complete strangers. Generally as in a real life consumers more trust the opinion of each other than different advertisements.

According to a survey of the Russian consumers, in addition to the personal recommendations of their friends, the Internet has become a major information resource and a place for a purchasing decision making. The active development of social networks and services in recent years has had a strong impact on the way how millions of users around the world communicate, shop and take brands.

\section{Results}

Creating a website is difficult and rather expensive, so we recommend for small businesses to create a community in blogs, groups, social networks and promote in these spaces, in a social sphere, getting a very significant effect with better returns than in the case of the site development and with more active users.

The following table lists as described above, some of small businesses economic activities and social networks which are preferable to develop their business, as well as the main ways of products and services promoting in these networks. 
Table 1. Small businesses promotion of goods and services in different social networks.

\begin{tabular}{|c|c|c|c|l|}
\hline $\begin{array}{c}\text { Small businesses } \\
\text { in Russia }\end{array}$ & $\begin{array}{c}\text { Social network } \\
\text { Vkontakte }\end{array}$ & $\begin{array}{c}\text { Social network } \\
\text { Odnoklassniki }\end{array}$ & $\begin{array}{c}\text { Social network } \\
\text { Instagram }\end{array}$ & $\begin{array}{c}\text { The main ways to promote ones products and services using social } \\
\text { network }\end{array}$ \\
\hline Wholesale and retail & + & + & $\begin{array}{l}\text { Placing texts, links, photos, video and hashtags. Variety of content increases } \\
\text { coverage and user involvement. A selection of different photos from a } \\
\text { storefront, dialogues with subscribers in the form of questions, corporate } \\
\text { news, photos of a new products range. } \\
\text { A variety of events: flash mobs, discounts and coupons, themed photo } \\
\text { contests. }\end{array}$ \\
\hline $\begin{array}{c}\text { Hotels and } \\
\text { restaurants }\end{array}$ & + & + & + & $\begin{array}{l}\text { Text, links, photos, and videos: workflows; photos of dishes, menu, hotel } \\
\text { rooms photos, photos of satisfied customers; celebrities holding various } \\
\text { competitions; special offers; active dialogue in the comments and hashtags. }\end{array}$ \\
\hline $\begin{array}{c}\text { Operations with real } \\
\text { estate, renting and } \\
\text { services }\end{array}$ & + & + & $\begin{array}{l}\text { Text, links, photos, and videos: workflows; photos of real estate, renting } \\
\text { photos, etc. }\end{array}$ \\
\hline $\begin{array}{c}\text { Education, health } \\
\text { Textile and clothing } \\
\text { manufacture }\end{array}$ & + & + & $\begin{array}{l}\text { Text, links, photos, and videos: Master classes, A variety of events: flash } \\
\text { mobs, discounts and coupons, themed photo contests. }\end{array}$ \\
\hline $\begin{array}{c}\text { Production of } \\
\text { leather, leather } \\
\text { products and shoe } \\
\text { production }\end{array}$ & + & + & $\begin{array}{l}\text { Text, links, photos, and video, photos of new products, sketches, public } \\
\text { opinion survey, dialogue with subscribers. New products range, manufacture } \\
\text { photo and video. A variety of events: flash mobs, discounts and coupons, } \\
\text { themed photo contests. }\end{array}$ \\
\hline $\begin{array}{c}\text { Publishing, printing, } \\
\text { advertising }\end{array}$ & + & + & $\begin{array}{l}\text { Text, links, photos, and video, photos of new products, sketches, public } \\
\text { opinion survey, dialogues with subscribers. New products range, manufacture } \\
\text { photo and video. A variety of events: flash mobs, discounts and coupons, } \\
\text { themed photo contests and hashtags. }\end{array}$ \\
\hline
\end{tabular}

According to the information above, it can be concluded that the social network Instagram is ideal for small businesses if it is connected with: family; fashion; gadgets and electronics; architecture; sports; food; travel. In fact, this list is not a strict restriction but only a recommendation for the most successful and rapid onset of the campaign in this social network on the basis of its preferences. Making products real can be a tough challenge for online businesses, because customers can't see, touch and smell products first-hand. But visuals can deliver those sensual experiences, too [11].

As a result of the study, we would like to propose a calculating formula of the indicator which shows the number of potential buyers for a separate account in Instagram.

Qi = S / L

Qi - index number (quantity) of potential buyers in Instagram (i);

$S$ - total number of subscribers (users) of the user (account);

L-total number of likes (one photo / one item).

The indicator of potential buyers number in Instagram (Qi) depends on the following factors:

- gender of the potential (prospective) buyer;

- $\quad$ Age of the potential buyer;

- Solvency of the potential buyer;

- Taste (preferences) of the potential buyer, and so on.

Thus you can calculate the approximate number of potential buyers for any business account in Instagram.

Such services as social networks, blogs and microblogs succeeded in attracting an audience of millions. And the world's largest companies, including market leaders in the retail trading and food production use the Internet in their marketing strategy, as their target audience, their customers are there. Social media has become an effective tool for the study of opinions about the brand, allowing you to work directly with customers to get feedback on existing products and suggestions for improvement.

\section{Conclusions}

The information economy opens new opportunities for small businesses in Russia. An increasing number of small businesses are striving to integrate the Internet - communities, as now all companies and individual entrepreneurs have realized the importance of business promotion in several areas. It is especially important to contact and "get closer" to the 
potential customers. Communicating with customers through social networks, it is possible not only to attract new ones, but also increase the loyalty of regular customers. Meanwhile, one can create a community in blogs, groups, social networks and promote in these spaces, in a social sphere, getting a very significant effect with better returns than in the case of developing the site and with more active users. The main trend will be increasing of the number of different communities, groups and business accounts in social networks, by gaining the number of Internet users and the growth of their interaction with small businesses.

For the modern Russian economy is characterized limited capacity to overcome the crisis in the economy owing to the underdevelopment of market instruments, the lack of a system of economic policy orientation[12], for that reason small businesses need to develop any possible ways the information economy provides.

\section{References}

Federal state statistics service. Russian statistical Yearbook - 2013. Electronic resource: access mode - http://www.gks.rul $\mathrm{bgd/regl/b13 \_ 13/Main.htm.}$

McIntyre D.P., Chintakananda A. 2014. Competing in network markets: Can the winner take all? / Business Horizons, vol 57, Issue 1, pp.117-125.

DeMers J., 2014. The Top 7 Online Marketing Trends Dominating 2014 // Forbes, Electronic resource: access mode- http://www.forbes. com/sites/jaysondemers/2014/07/22/the-top-7-online-marketing-trends-dominating-2014/.

Marshall P., 2013. 80/20 Sales and Marketing: The Definitive Guide to Working Less and Making More. Publisher: Entrepreneur Press, pp.134-136

Labrecque L. I., Esche J., Mathwick C., Novak T.P., Hofacker C. F., 2013. Consumer Power: Evolution in the Digital Age // Journal of Interactive Marketing, Volume 27, Issue 4, pp. 257-269.

Habibi M. R., Laroche M., Richard M., 2014. The roles of brand community and community engagement in building brand trust on social media // Computers in Human Behavior. Volume 37, pp.152-161.

Magedanz T., Simões J., 2009. What happens when you mix social networks, contexts and mobile advertising in the same glass? // International Journal of Mobile Marketing, Vol. 4 no. 2, pp.56-66.

Lazarev D. 2014. Overview of social networks in Russia 2014. Electronic resource: access mode - http://www.cossa.ru/articles/149/ $64848 /$.

Kononova K. 2012. Social Networks: Modeling of Competitive Interactions

// Procedia Economics and Finance, Volume 1, pp. 249-258.

Miles J. G., 2013. Instagram Power: Build Your Brand and Reach More Customers with the Power of Pictures. Publisher: McGraw-Hill; pp.211-213.

Mallikarjunan S., Ewing M., 2012. Inbound Commerce - How to Sell Better than Amazon - Infinity Publishing, pp.132-142.

Grigoreva E., Fesina E., 2014. Economic Security as a Condition of Institutional Support of Economy Modernization/ World Applied Sciences Journal 31 (5),pp.940-948.

Vakhitova T., Gadelshina L., Shikhalev A., Ullubi S. 2013. Foreign economic and interregional relations of the Russian Federation subjects (the case of The Tatarstan Republic): analysis and predictions // World Applied Sciences Journal 27 (7), pp.939-943.

Pereira H.G., Salgueiro M., Mateus I. 2014. Say yes to Facebook and get your customers involved! Relationships in a world of social networks // Business Horizons. Volume 57, Issue 4, pp.492-497. 